\title{
CHST3 Gene
}

National Cancer Institute

\section{Source}

National Cancer Institute. CHST3 Gene. NCI Thesaurus. Code C116934.

This gene is involved in proteoglycan sulfation. 